IdeAs

Idées d'Amériques

$14 \mid 2019$

Populismes dans les Amériques

\title{
Magda Sepúlveda Eriz, Gabriela Mistral. Somos los andinos que fuimos
}

Santiago du Chili, Editorial Cuarto Propio, 2018, 196 pages

\section{Malva Marina Vásquez}

\section{OpenEdition}

\section{Journals}

Edición electrónica

URL: http://journals.openedition.org/ideas/6296

DOI: $10.4000 /$ ideas. 6296

ISSN: 1950-5701

Editor

Institut des Amériques

Referencia electrónica

Malva Marina Vásquez, " Magda Sepúlveda Eriz, Gabriela Mistral. Somos los andinos que fuimos », IdeAs [En línea], 14 | 2019, Publicado el 01 octubre 2019, consultado el 23 septiembre 2020. URL http://journals.openedition.org/ideas/6296 ; DOI : https://doi.org/10.4000/ideas.6296

Este documento fue generado automáticamente el 23 septiembre 2020

\section{c)}

IdeAs - Idées d'Amériques est mis à disposition selon les termes de la licence Creative Commons Attribution - Pas d'Utilisation Commerciale - Pas de Modification 4.0 International. 


\title{
Magda Sepúlveda Eriz, Gabriela Mistral. Somos los andinos que fuimos
}

\author{
Santiago du Chili, Editorial Cuarto Propio, 2018, 196 pages
}

Malva Marina Vásquez

\section{REFERENCIA}

Magda Sepúlveda Eriz, Gabriela Mistral. Somos los andinos que fuimos, Santiago du Chili, Editorial Cuarto Propio, 2018, 196 pages

1 El ensayo de la académica de la Universidad Católica de Chile, Magda Sepúlveda Eriz, es una contribución a los estudios de la recepción mistraliana. Hasta la fecha, no contábamos con un riguroso estudio del imaginario andino en su poesía. A través de sus seis capítulos, la autora analiza el cuestionamiento que hace Mistral del relato oficial de la nación burguesa chilena, relato de negación de las etnias y del dominio del español hispanoamericano, en tanto que "lengua de traducción colonial" (Mignolo, Walter, La idea de América Latina..., 2007). Sepúlveda descodifica las imágenes y performance de un imaginario trasandino en estos poemarios, los que aparecen signados por una radical subalternidad o "herida colonial." Eso confirma el aserto de Cornejo Polar, respecto a "la heterogeneidad esencial" de las literaturas nacionales, ya que en nuestra modernidad, coexisten tiempos truncos y mixtos de premodernidad, modernidad y postmodernidad.

Un aspecto a relevar es su diálogo con el archivo iconográfico mistraliano, lo que lo acerca al libro-imagen y a la crítica de los estudios culturales: cada uno de sus apartados dialoga, ya sea con una imagen documental o de las artes plásticas de connotados artistas visuales chilenos. La autora parte su análisis por el Mural realizado por Fernando Daza (inaugurado en 1971, bajo el gobierno de la Unidad Popular) para desmontar el imaginario nacional que monumentaliza la figura de la Mistral y rescata a la escritora de su filiación a una mitología al servicio del Estado; la de maestra y/o madre patriótica. Para Sepúlveda, Mistral ha sido vanguardista por actualizar "las 
formas retóricas del mundo incaico" (17), y por dar un fiel testimonio poético de "los documentos de barbarie del Estado Chileno" (54). La tesis es que, través de estas prácticas, Mistral deconstruye la presunta homogeneidad del mito "nación" al proponer una subjetividad de tipo transnacional, la de la región cultural andina.

3 Esta lectura de la codificación poética de "un nosotros andino" se despliega en forma brillante en el análisis de los poemarios, aunque por momentos, se tornen demasiado porosas las fronteras entre la ficción poética de la "indiada" y los aspectos biográficos de la poeta. Sin embargo, esta asunción del linaje trasandino en Mistral, no puede obviar el hecho de que el género discursivo que vehicula este imaginario es de alta cultura. En efecto, esta maestra de "nuestra América" se posiciona tempranamente en 1914 - con la obtención del premio de La Flor Natural del Concurso de los Juegos Florales con sus "Sonetos de la muerte" - como figura relevante de la ciudad letrada patriarcal. De ahí que, en tanto que voz ya canonizada, Mistral comente: "no se esperaba que yo ni nadie fuera a defender lo indefendible, la indiada" (180).

4 Debido a que el humanismo rural andino mistraliano sería de denuncia de "los documentos de barbarie del Estado Chileno", es coherente que se dé en los poemarios la inversión del designio colonizador, civilizador, de Occidente. En la poética mistraliana, se reconoce la positividad de esa barbarie originaria frente a los modelos culturales del dominador, representados por el proyecto republicano de carácter homogeneizante y universalista.

5 Así, el primer capítulo del ensayo "Ante la Patagonia colonizada, el poemario Desolación" (1922) es leído como "el ejercicio de pasar por la historia el cepillo a contrapelo" (Benjamin), en relación a desocultar esa "tradición de los oprimidos." Esto es, el exterminio de los indígenas patagónicos por el Estado chileno. Y, a la vez, como duelo o "canto fúnebre" por las ruinas que deja la deforestación de la Patagonia chilena. El balance crítico de estos devastadores efectos de la violencia genocida de la colonización y la discriminación racial de la República criolla, conducen al hablante lírico a concluir que "no es posible prolongar la estirpe de los vencidos" (Sepúlveda, 52).

6 Cabe destacar que esta lectura de un imaginario trasandino en la poesía mistraliana, trasunta rasgos de una utopía arcaica que guarda muchas afinidades con la de Arguedas, ya que, según la ensayista, Mistral "no cree en la modernidad de la fábrica, como espacio de liberación, sino en permanecer en lo agrario" (35). En este sentido, es crucial el poema "Canción amarga" donde Mistral aboga por la restitución de las propiedades a los indígenas, ya que "era una intelectual pro reforma agraria antes que este concepto se promoviera en Chile" (87-88). A la reivindicación de otra forma de productividad, que la de la modernidad capitalista, en el apartado segundo, que analiza el poemario Ternura (1924), se agrega la problemática de género. Aquí, Mistral abogaría por la necesidad de una política de salud pública, que defienda los derechos de las madres solteras indígenas. En el apartado tercero, "Otra vez somos los andinos que fuimos, Tala" (1938) se refuerza la tesis de que Mistral no sería una renegada o una "aculturada" de su linaje andino. El reconocimiento de su subjetividad andina se plasmaría en su poema "Sol del trópico", escrito a los 40 años.

7 La estadía de la Mistral en la Patagonia chilena, donde vio el genocidio de los indígenas australes, como su estadía en México a los 33 años, son vivencias claves. Este poema es central para entender la valoración, en términos de autenticidad cultural que asigna Mistral a la oralidad y a lo comunitario indígena, frente a lo foráneo de religiosidad 
protocolar y libresca (103). Sin embargo, en el apartado 4, "El costado feminista de Gabriela Mistral Lagar (1954)", Sepúlveda constata un sincretismo entre el imaginario andino y el católico, acercando su exégesis a la metáfora de la hibridez poética, entre los modelos pictóricos europeos y el paisaje andino. Lectura que relativiza la afiliación cultural andina de Mistral, mostrándola más bien como sujeto letrado de nuestra modernidad periférica, como un "sujeto bifronte" (Sarlo). En efecto, en nuestra modernidad, conviven en permanente tensión, tradiciones premodernas, unidas a prácticas políticas, educativas y comunicacionales modernas, lo que ha generado "formaciones híbridas en todos los estratos sociales" (García Canclini, Culturas Híbridas, 1990, 71).

8 En el apartado 5 "No te digan indio pata rajada. Poema de Chile (1967)", Mistral reivindicaría como cultura de origen la cultura mapuche, al entenderla como nuestra "Vieja Patria". En éste se recrea la familia latinoamericana andina, formada por "huachos y madres." Una especie de matriarcado de una mujer que vaga con un niño atacameño, a la manera de una madre soltera. El apartado final "Dime, Gabriela. Personaje y agencia literaria," la muestra como una raris avis en las letras chilenas, por su renuencia a participar a los grupos de vanguardia y en los salones literarios de la élite criolla. Su cambio de nombre, su trashumancia, y su valoración de actitudes que no se correspondían al modelo mariano de beatitud, la muestran en disidencia con los valores del ideal regulatorio de familia y nación burguesa. Sepúlveda destaca en Mistral un feminismo de otro cuño que el de la búsqueda de igualdad política por parte del Partido Cívico Femenino (1920) y el Movimiento Pro Emancipación de las Mujeres de Chile, (1935). Su feminismo pone el énfasis en la problemática social de las madres indígenas y solteras.

9 Sepúlveda plantea que, en el ámbito público, fue la asunción del estilo táctico de una actitud ladina, la estrategia que le habría permitido a Mistral, sortear los escollos que le presentara su tiempo. Actitud que vemos poetizada en "El maíz": "Braceo en la oleada/ como el que nada siempre/(..)/riendo risa india/que mofa y consiente (...)/ braceándole la vida/braceándole la muerte" (Tala op. cit, 186). Esta actitud "que mofa y consiente", da cuenta de "una desobediencia poscolonial mujeril" (186). La subjetividad femenina latinoamericana, según Mistral, se caracterizaría por la impronta de resistencia cultural, frente a los embates civilizadores de carácter disciplinario: "Querer reducir a normas y poner en perfil neto nuestro capricho consuetudinario, es una empresa de romanos que nosotras podemos desbaratar entera, fingiendo que la obedecemos" (Mistral, Conferencia en Montevideo, 1938).

La falta de reconocimiento a las etnias delata una falla simbólica en nuestra nacionalidad, lo que redundaría en una pérdida de espesor cultural que impide las prácticas de negociación intercultural. Por ello un quehacer acuciante en la poética mistraliana sea el dignificar los rituales comunitarios y la retórica de la oralidad andina. Pero, a nuestro parecer, si bien la ensayista da pruebas de una magistral exégesis de la poética mistraliana, no parece estar dispuesta a relativizar su gesto político de leerla como la celebración de una utopía trasandina. Esta opción de homologar el imaginario andino poetizado con lo que llama "el ideario político mistraliano", la conduce a ratos a obliterar la instancia de mediación "transculturadora" letrada. Esto conlleva el riesgo de adherir a un etnocentrismo invertido. O sea, al otorgar Sepúlveda valor de autenticidad a las culturas vernáculas, éstas adquieren una primacía ontológica en tanto se entienden como culturas de la 
presencia (de la oralidad) por sobre la cultura letrada (la escritura). Lo cual podría conducir a adoptar una postura metafísica logocéntrica; la que tiende a privilegiar una phoné natural. Pero, tal como lo advirtiera Rama en La ciudad letrada: "La modernidad no es renunciable y negarse a ella es suicida; lo es también renunciar a sí mismo para aceptarla". Así, Sepúlveda, en el apartado "Imaginario social", plantea: "Los grupos imponen sus significados mediante procesos de negociación con sus adversarios. Cuando no hay negociación hay "otros", hay enemigos y hay exterminio" (35).

El encargo mistraliano de un humanismo andino habría que entenderlo bajo el imperativo de no seguir siendo unos "renegados" o "aculturados" (Arguedas) de nuestro linaje andino. De ahí que esta reivindicación de una cultura vernácula ponga en cuestionamiento la monocultura del saber o cultura hegemónica que a su vez ha engendrado formas monológicas de violencia física y simbólica. Como plantea la ensayista, frente a la lógica productivista, asentada en la monocultura del crecimiento capitalista, Mistral dignifica y promueve la ecología de los saberes andinos, sus productividades alternativas y los reconocimientos a las etnias invisibilizadas por el proyecto de nación moderna. Este ideario mistraliano muestra ser la única hoja de ruta que nos puede conducir hacia "una pluralización epistemológica" (De Sousa Santos, Una epistemología del Sur, 2009). Cabe pues preguntarnos si ya como nación o "comunidad imaginada" seremos capaces de desmantelar la colonización epistémica del pensamiento binario y universalista del imaginario nacionalista, basado en conceptualizaciones homogéneas y excluyentes. 